\title{
Hotel Ukraina. Bohdana Zadury wiersz o przyjmowaniu uchodźców
}

\author{
Ukraine Hotel by Bohdan Zadura as a poem about \\ recipience of refugees
}

\author{
Katarzyna Kuczyńska-Koschany
Uniwersytet im. Adama Mickiewicza w Poznaniu
}

\begin{abstract}
The article is raising the refugees issue in reference to the poem Ukraine Hotel by Bohdan Zadura, published in his book Final touch (2014). The poem was written as a spontaneous reaction on the pacification of the Maidan in Kiev in February 2014. Therefore the author of the article is sketching wide contextual background, she recalls reportages, essays and interviews which explain the core of the conflict. The article collects materials useful during school lessons asking the questions: who is (or who can be) a refugee and if I am ready to welcome such a person under my roof?
\end{abstract}

Key words: Bohdan Zadura, Ukraine, Maidan, refugees, welcome gesture

Streszczenie: Tekst podejmuje problem uchodźczy w odniesieniu do wiersza Bohdana Zadury Hotel Ukraina z tomu Kropka nad i (2014). Wiersz został napisany jako spontaniczna reakcja na pacyfikację kijowskiego Majdanu w lutym 2014, dlatego autorka szkicuje szerokie tło kontekstowe, przywołując reportaże, eseje i rozmowy, które przybliżają sedno konfliktu. Tekst gromadzi zatem materiały do lekcji na temat: kim jest (lub może być) uchodźca i czy ja sam(a) jestem gotowy(a) przyjąć taką osobę pod swój dach?

Słowa kluczowe: Bohdan Zadura, Ukraina, wiersz, Majdan, uchodźcy, gest przyjęcia

Ilji, nowemu uczniowi w 5d

Wiersz ukazał się w „Gazecie Wyborczej” (14 marca 2014), czyli po rzezi kijowskiego Majdanu (20 lutego 2014), a datę jego powstania - 23 lutego 2014 - poeta zachował także w wydaniu książkowym, w tomie poetyckim Kropka nad i (Biuro Literackie, 2014). Kilka dni po powstaniu wiersz był już przełożony na ukraiński przez Andrija Lubkę, jednego z wymienionych w tekście przyjaciół Ukraińców. Pod takim zresztą tytułem wiersz krąży na forach internetowych: jako „wiersz dla przyjaciół Ukraińców” (analogicznie do słynnej Mickiewiczowskiej formuły, związanej z powstaniem dekabrystów: „Do przyjaciół Moskali”). 
W ciągu trzech ostatnich lat pojawiło się w Polsce wiele publikacji na temat ukraińskich doświadczeń, wywołanych przez rezygnację Wiktora Janukowycza - wbrew woli większości mieszkańców tego kraju - ze wstąpienia Ukrainy do Unii Europejskiej. Wymienię jedynie znakomitą pracę zbiorową Zwrotnik Ukraina (omawianą na łamach „Polonistyki. Innowacji” w 2015 roku), rozmowy Pawła Smoleńskiego z najwybitniejszym bodaj ukraińskim pisarzem, Jurijem Andruchowyczem, zatytułowane Szcze ne wmerła i nie umrze (2014), czy książkowy reportaż Zbigniewa Parafianowicza i Michała Potockiego pt. Wilki żyja poza prawem. Jak Janukowycz przegrał Ukraine (2015). Wiersz Zadury - znawcy i przyjaciela Ukrainy, tłumacza literatury ukraińskiej, człowieka głęboko zaangażowanego w dialog ukraińsko-polski, a jednocześnie wybitnego polskiego poety - wraca do mnie wciąż i nic nie utracił z mocy swego poetyckiego przekazu. Napisany spontanicznie i niejako interwencyjnie, zanim Europa i Polska stanęły przed decyzją o przyjmowaniu bądź nieprzyjmowaniu uchodźców z Syrii, teraz w sposób niezwykle przejmujący „zabiera głos” w dyskusji.

\section{Tytuł}

Przesłanie wiersza jest czytelne, trudno go nie zrozumieć, a przecież brzmi zupełnie inaczej niż - nawet najbardziej przekonujące, nabrzmiałe od sensownych argumentów - debaty. Brzmi wiarygodnie. Opowiada o tym, że ludzie przyjmują innych ludzi. (Albo nie).

Zadura zadaje to jedno podstawowe pytanie: czy w naszych domach czekają na wojennych uchodźców pokoje widmowego hotelu Ukraina - pokoje dla uciekinierów z Krymu czy Donbasu (dziś można by napisać wiersz pt. Hotel Syria i całe piętro czy skrzydło tego hotelu nazwać Aleppo)? To teraźniejsza perspektywa - wtedy, w lutym 2014 roku, nie było jeszcze wiadomo, że Rosja zaatakuje Ukrainę i zajmie część jej terytorium.

W mojej prywatnej i pierwszej lekturze wyobraźnia bierze się z tytułu. Najpierw usłyszałam tytuł tego wiersza, przypomniałam sobie wstrząsający film pt. Hotel Rwanda i wyobraziłam Polskę właśnie jako hotel dla dotkniętych wojną Ukraińców, a dopiero potem - gdy przeczytałam tekst - zrozumiałam, że Zadura pisze o istniejącym w Kijowie hotelu i na własnym déjà vu (poeta mieszkał kiedyś w Hotelu Ukraina) buduje koncept wiersza. Oto Ukraina staje się hotelem dla samych Ukraińców; według Janukowycza (czytaj: Putina) są obywatele tego państwa jedynie - już nieproszonymi - gośćmi na przejętym terytorium. Hotel zamienia się w „polowy szpital / i kostnicę". Majdan, który był agorą, staje się grobem.

\section{Wiersz}

Oto ten bardzo długi wiersz (jak bywa droga uchodźcy), litanijny (dystychy są tu klasycznie enumeracyjne), a dla mnie także pełen znajomych i przyjaciół (wiele spośród wymienionych u Zadury osób miałam 
szczęście poznać podczas kilkukrotnych pobytów w Ukrainie - we Lwowie, Drohobyczu i Czerniowcach):

czy wpuściłbyś pod swój dach

uchodźcę z Ukrainy? -

pyta internetowy portal

Andrija Bondara i Sofijkę

nawet z dzieckiem

i z teściami

tak

ale czy także

z dwoma psami

tego nie wiem

Bojczenków

całą trójkę

Hałynę Kruk

nawet z nowym facetem

Katię Babkinę

nawet starszą o dwadzieścia lat

Dmytra Pawłyczkę

nawet osiemdziesięciopięcioletniego

Lubow Jakymczuk

nawet w ciąży

Dzwinkę Matijasz nawet z siostrą Bohdaną

i Bohdanę Matijasz nawet z siostrą Dzwinką

Saszkę Irwancia z Oksaną

Natałkę Biłocerkiweć z Mykołą

Mykołę Riabczuka z Natałką

Pawła Szczyrycię nawet z wrzodami

na żołądku

Wierę Meniok i małą Wierkę

z Drohobycza

i Lonię Goldberga również stamtąd

choć niech nie liczy że mu potwierdzę

na Lindekinie że jestem

jego znajomym

Serhija Żadana

choć jest z Charkowa

Polonistyka. Innowacje 
Saszkę Kabanowa

choć pisze rymowane wiersze

i robi to po rosyjsku

Andrija Lubkę

bez zastanowienia

i Neboraka Kijanowską Beleja

Strongowskiego i Sływynskiego

Semenczuka i Wynnyczuka

Łyszehę i Danę Pinczewską

i kobietę która się ukrywa pod

nickiem verandabalkonowa

i w księgarni E

w 2010 dostałem od niej

liścik

i Maryjkę Martusewicz Igora Biełowa Wasyla Machnę

no nie Maryjka to Białorusinka Igor to Rosjanin

a Machno od czternastu lat

mieszka nie w Tarnopolu a w Nowym Jorku

więc najpierw niech Amerykanie

zniosą dla Polaków wizy

z lewej strony ekranu napis:

NA ŻYWO: krwawe starcia w Kijowie

wchodzę na espreso.tv

a właściwie jego retransmisję

strzały

barykady

płonące opony

morze głów

z hotelem Ukraina w tle

przemówienia

od czasu do czasu

zagłuszane

przez reklamy pasty do zębów

w hotelu Ukraina

późną ciepłą jesienią

2012 przez dwa dni

mieszkałem na piątym piętrze

$\mathrm{z}$ widokiem na Majdan

późnym wieczorem

wracałem z Arsenału 
ulicą Instytucką

w barku przy recepcji

piłem z kimś koniak zakarpacki

kto to był może Leś Belej

nie pamiętam

ale $\mathrm{z}$ lotniska odbierała mnie

i odwoziła do Boryspola

Ola Bratczuk

i ją też bym wpuścił

pod swój dach

oglądam zdjęcia w internecie

ten hol na dole

gdzie wtedy prócz recepcjonistki

nas dwóch i jakiejś kobiety

gotowej zająć się

czyjąś samotnością

nie było nikogo

zamieniony

na polowy szpital

i kostnicę

w puławskim mieszkaniu

dobiegają mnie głosy z podwórka

harmider krzyki jakieś śpiewy trzaski

podchodzę do okna

wychodzę na balkon

to uchodźcy z Ukrainy

domagają się by ich wpuszczono

do mieszkań

są agresywni

krzyczą

sława Ukraini herojam sława

nikt do nich nie wychodzi

nikt im nie otwiera

dziwi mnie

że wybrali tylko

dwie pierwsze klatki

zupełnie nie zainteresowani

tą w której mieszkam

budzę się w warszawskim mieszkaniu

słyszę te same głosy co we śnie

Polonistyka. Innowacje

Numer 6, 2017 
na ekranie telewizora

prjama translacja z Majdanu

wstyd mi kochani

że tym bardziej

jestem z wami

im bardziej nie słyszę

waszych przywódców

i wszystkich

którzy mówią

do was ze sceny

również po polsku

\subsection{2. $2014^{1}$}

Zaczyna się od, zdawać by się mogło, odpowiedzi na pytanie retoryczne. Ileż jest takich pytań portali internetowych, których nie traktujemy poważnie. Czy zrobił(a)byś to, czy zrobił(a)byś tamto? Polski poeta odpowiada bardzo serio, chociaż odpowiedź ta nie ma za grosz znamion utopijnego altruizmu. Zadura - nie naruszając tonacji serio - jest czuły, ciepły, uśmiecha się niektórymi wersami, nawet żartuje.

Wiersz jest bardzo uczciwy. Nie unika mówienia o strachu - wszyscy ludzie, którzy przyjmują innych ludzi (uchodźców), boją się. Przynajmniej niewygody, braku dotychczasowego komfortu, co poeta traktuje prawie humorystycznie. Miejsce dla zaprzyjaźnionych osób się znajdzie ze wszystkimi „nawet” i „bez wahania”, ale czy dla zwierząt - już nie wiadomo:

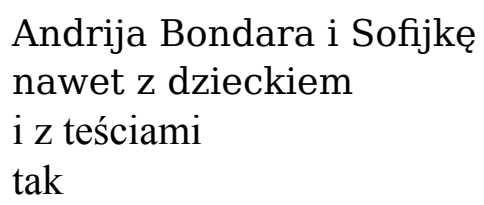

Czasem ludzie przyjmujący innych ludzi pod swój dach boją się czegoś więcej: agresji, roszczeń, własnych uprzedzeń. Empatia, znana z teorii, ale istniejąca - jak wiadomo - jedynie w praktyce, zostaje wystawiona na poważną próbę, gdy okazuje się, że uchodźcy to nie bezładna i dzika masa, składająca się z samych terrorystów islamskich albo nacjonalistów ukraińskich, lecz pojedyncze osoby, mające imię i nazwisko. Te osoby coś straciły lub mogą się obawiać nadchodzącej utraty: życia, pracy, zdrowia, mieszkania. Bezradność i poczucie zagrożenia, ale także brak horyzontu i sensu

${ }^{1}$ Zadura Bohdan, 2014, Hotel Ukraina, w: Kropka nad i, Wrocław, s. 68-72 (dalej skrót - HU wraz $\mathrm{z}$ numerem strony). 
własnych działań popychają takie osoby do nagłej albo długo odkładanej decyzji o uchodzeniu z własnego kraju, o opuszczaniu domu i ojczyzny - na długie lata, czasem na zawsze.

I Zadura pokazuje bez retuszu te sprzeczne emocje, dotyczące także poety, piszącego wiersz-odpowiedź na pytanie portalu internetowego, własny wstyd, własną - osobistą, niewynikającą z decyzji przywódców państwowych - solidarność:

\author{
wstyd mi kochan \\ że tym bardziej \\ jestem z wami \\ im bardziej nie słyszę \\ waszych przywódców \\ i wszystkich \\ którzy mówią \\ do was ze sceny \\ również po polsku \\ (HU, 72)
}

\title{
Niebiańska sotnia (nebesna sotnia), czyli przed czym uchodzi uchodźca
}

Po wstępnych rozpoznaniach, pierwszych przymiarkach lekturowych, spróbuję zbudować kontekst dla dalszych rozważań. Przytoczę dwie relacje, obie wiarygodne, obie przerażające. Jedną z samego środka wydarzeń - Jurij Andruchowycz był blisko i opowiedział o tym Pawłowi Smoleńskiemu. Drugą - zapisaną jako śledztwo dziennikarskie - w reportażu Wilki żyja poza prawem.

Andruchowycz mówi do Smoleńskiego (Szcze ne wmerła..., 49-50):

Majdan był w bardzo trudnej sytuacji, gdyż ludzi z samoobrony akurat tej nocy zostało bardzo niewielu. Cudem wytrzymali noc z 18 na 19 lutego. Wiedzieliśmy wszystko, na bieżąco dostawaliśmy informacje, bo Ulana, nasza aktorka, miała na Majdanie bliskiego krewnego, Andrija Miszczenkę, chłopaka ze Lwowa, ale posła Swobody. Ulana rozmawia z Andrijem tuż po naszym spektaklu. Słyszy: $<<$ Nie mogę długo gadać, strzelają, zostaniemy tu do ostatniego, jutro nas nie będzie $>>$. (...)

W tym samym czasie dostajemy informację, że Majdan odpowiada na milicyjne kule ogniem. Daję głowę, że Berkut wiedział, że na Majdanie jest broń. Wszyscy wiedzieliśmy, kiedy stało się jasne, że albo my, albo oni. Ale milicjantom wtłoczono do łbów, że tylko oni mogą zabijać, że nikt do nich nigdy nie strzeli. Uwierzyli, dlatego byli po prostu przerażeni. Nagle poczuli, że mogą stracić życie dla jakiegoś Janukowycza. Na dodatek samoobrona podpaliła koktajlami Mołotowa policyjny wóz pancerny. Niby to marne posowieckie badziewie, zapala się bardzo łatwo i każdy łepek po wojskowym przeszkoleniu wie o tym znakomicie, ale milicja się przestraszyła, wpadli w panikę. Dotychczasowa bezkarność po prostu ich zdemoralizowała. (...) Berkut gieroje - tak o sobie myśleli. Nie spodziewali się poważnego oporu, do głowy im nie przyszło, że skoro oni strzelają, do nich też można strzelać. Jeśli już, to byli przygotowani na walkę z kilkoma setkami chłopaków uzbrojonych w kije.

I dalej (Szcze ne wmerła..., 56): 
Nagle, tak koło południa, kiedy wiadomości o rozstrzeliwaniu Majdanu poszły szeroko w świat, dzwoni pierwszy telefon, a potem następny i następny, zaczyna się koncert na kilkadziesiąt dzwonków, wybrzmiewa kakofonia różnych sygnałów. Ona [dziewczyna z Winnicy w punkcie medycznym Majdanu - przyp. KKK] odbiera te telefony po kolei, ale zanim powie: „Przykro mi, nie żyje, zabili go”, musi nacisnąć jakiś klawisz i spojrzeć na wyświetlacz. Ma dość, bo na jednym, drugim, trzecim, kolejnym ekranie wyświetla się słowo „mama”. Płacze, ale nie wolno jej pokazać słabości, czuje się podle, nie chce tej roboty, ale wie, że musi ją wykonać. Niby nic, to tylko informowanie matek dwudziestoletnich gówniarzy, że dziecko właśnie zostało zastrzelone przez milicję: bardzo mi, proszę szanownej pani przykro, rewolucja. Majdan serdecznie współczuje. Przecież to przekracza ludzką wyobraźnię i wytrzymałość.

Ostatnie dni Majdanu utkane są właśnie z takich opowieści. Żadna martyrologiczna podniosłość, choć ta z pewnością też się kiedyś pojawi, tylko małe, często heroiczne drobiazgi, na które nie potrzeba wielu słów. Prawie wszystkie mają w sobie śmierć młodych ludzi, którzy powinni dzisiaj żyć, a przez tych bydlaków nie żyją.

Na pytanie Pawła Smoleńskiego, czy „unijni ministrowie namawiali waszych przedstawicieli do rozwagi", Jurij Andruchowycz odpowiada ze straszną, bolesną ironią (Szcze ne wmerła..., 58-59, podkreśl. KKK):

Nierozważni to byli ci gówniarze, którzy pierwszego wieczoru przyszli na Majdan, bo Janukowycz zakpił z ich marzeń. W ogóle bardzo nierozważne były marzenia o Ukrainie w Europie, o wolności, o demokracji.

Sam Majdan to czysta rozwaga, przezorność, roztropność, wielka ostrożność. Ale wszystko to kończy się w momencie, gdy milicja traktuje cię jak tarczę strzelniczą. Wtedy dosłownie walczysz o życie i nic więcej się nie liczy.

Nie dopatruję się w postawie unijnych ministrów żadnego spisku ani nawet zimnego politycznego wyrachowania. Widzę za to naiwność, brak zdecydowania i wiary, że Majdan naprawdę walczy tyle miesięcy w imię wartości, które Europa bez przerwy ma na ustach, ale w gruncie rzeczy traktuje je lekko. (...)

To nie tak, że ludzie nie czują wdzięczności za europejską solidarność z marzeniami Ukraińców. Tyle że czegoś w niej zabrakło. Zapłacili za to ludzie na Majdanie.

Polscy reporterzy, autorzy tomu Wilki żyja poza prawem, są oszczędni, ale precyzyjni. Mówią o tym, jak Kijów stał się miastem zamkniętym w nocy z 18 na 19 lutego; to, co MSW i służby specjalne określają jako „robienie porządku” (klasyczny eufemizm władzy używającej przemocy), Parafianowicz i Potocki nazywają wprost pacyfikacją. Szturm na Majdan zaczął się 18 lutego o 19.30 czasu kijowskiego. Oto fragment reportażu:

Najpierw było polewanie zimną wodą, granaty hukowe. Rebelia odpowiedziała koktajlami Mołotowa. Tradycyjnie już podpalono opony, które pełniły funkcję zasłony dymnej przed kulami Berkutu. Padła pierwsza barykada na Instytutśkiej, niedaleko hotelu „Ukrajina”. Oddziały milicji zaczęły nacierać także od Jewropejśkiej płoszczy. Do godziny dwudziestej drugiej zginęło piętnastu majdanowców i sześciu milicjantów. W nocy komandosi z Alfy i Omehy zaczęli obsadzać budynki wokół placu. Wokół nich byli snajperzy (Wilki..., 253). 
Potem był już ów czarny czwartek, 20 lutego 2014. I tu wystarczy jedno zdanie, Marcina Wojciechowskiego, który towarzyszył w Kijowie Radosławowi Sikorskiemu: „Mieliśmy wrażenie, że celem snajperów jest wypełnienie jakiejś normy śmierci" (Wilki..., 256).

To tę pierwszą barykadę, padającą przy hotelu Ukraina, widział prawdopodobnie Bohdan Zadura „NA ŻYWO” w relacji z Kijowa (zapisał wielkimi literami owo paradoksalne filmowanie śmierci - na żywo). To z ruin tej barykady poeta zbudował wiersz, to z reminiscencji pobytu w tym hotelu skonstruował los uchodźców i natychmiastową, hipertroficzną odpowiedź na pytanie: czy przyjąłbyś...?

\section{Bojczenko: $\mathrm{z}$ dystansu?}

Chyba nie ma dystansu w obliczu tragedii. Ale można spojrzeć na wydarzenia, nawet najtragiczniejsze, z pewnego oddalenia w czasie. Sięgam po książkę 50 procent racji Ołeksandra Bojczenki (dla przyjaciół - Saszy), wydaną w 2016 roku w Lublinie, w tłumaczeniu Zadury-ojca i Zadury-syna. To ten sam, wyśmienity stylistycznie, jedyny w swoim rodzaju eseista z Czerniowiec na Bukowinie, o którym jako kandydacie na uchodźcę, wraz z żoną Oksaną i córką Ołeksandrą, w wierszu Hotel Ukraina poeta pisał: „Bojczenków / całą trójkę”.

Poznałam Saszę Bojczenkę dobrze, spotkaliśmy się kilkakrotnie, gościliśmy nawzajem, w Czerniowcach (tuż przed Majdanem, kiedy rosły wielkie nadzieje na wejście Ukrainy do Unii Europejskiej - w końcu października 2013 roku; w tym samym czasie Władimir Putin stawiał ultimatum Wiktorowi Janukowyczowi - ale o tym wtedy jeszcze nie wiedzieliśmy) i w Poznaniu (latem 2017, po wielu miesiącach skrytobójczej wojny w Ukrainie). Jego głos to głos rozwagi, o którą upominał się w rozmowie z Andruchowyczem Smoleński. Jest to jednak rozwaga bolesna, dotykająca żywych ran. W szkicu Czyja ziemia? Bojczenko pisze (50 procent racji, 94):

Kiedy słyszę, jak ktoś - obojętnie z której strony - zaczyna bić się w piersi i dowodzić, że $<<$ to nasza ziemia >>, od razu wyobrażam sobie jednodniowego motyla na gałęzi tysiącletniej kalifornijskiej sekwoi. Przysiadł na niej, pełen planów na przyszłość i mówi: „Moja sekwoja”. Sekwoja, naturalnie, milczy w odpowiedzi, nie sprzecza się. Gdyż w czasorytmie swojego sekwojowego istnienia nawet nie zdoła zauważyć, że jakiś motyl tego ranka się narodził, przywłaszczył ją sobie, trochę potrzepotał i pod wieczór stulił skrzydła.

Na granicy Meksyku i USA snuje czerniowiecki eseista śmiałe rozważania (50 procent racji, 95):

sama ziemia jest identyczna - pod względem jakości i wyglądu nie odróżnisz, gdzie meksykańska, a gdzie amerykańska. Za to po jakości i wyglądzie tego, co na tej ziemi stoi, łatwo poznasz, gdzie działają amerykańskie prawa, a gdzie meksykańskie.

Uważam, że do czegoś takiego musi też dojść u nas. Prawo zakazujące komunistycznego plugastwa uchwalono? Uchwalono. No to zobaczymy, jak będzie ono „wdrażane”. 
Tam, gdzie wszystkie te leniny z dzierżyńskimi i towarzyszącymi im artiomami pozłażą z postumentów, tam tym samym działa ukraińskie prawo. Więc tam też - przynajmniej przez jakiś czas - jest Ukraina. A gdzie nie, tam nie.

\section{Lekcja Ukrainy, możliwość}

Wszystkie materiały na lekcję licealną są dane. Od nauczyciela będzie zależeć umiejętność ich zastosowania. Jak ułożyć kolejność? Czy rozpocząć od nakreślenia zaplecza: losów umowy stowarzyszeniowej Ukrainy z Unią Europejską, spontanicznej obrony demokratycznych zasad na kijowskim Majdanie i rozstrzelania niebiańskiej sotni? A wiersz zaproponować jako efekt solidarności, empatii, przyjaźni - jako przykład poezji zaangażowanej, a nie tylko interwencyjnej? Czy odwrotnie? Scenariusz zależeć będzie od temperamentu i wizji nauczyciela, a także od możliwości intelektualnych danej klasy.

Jedno jest pewne: tam, gdzie działa prawo wolnego kraju - jak pisze Bojczenko - „jest Ukraina” (albo: „jest Polska”). A tam, gdzie przedłuża się wojna, kryptonimowana eufemizmem „konflikt”, pojawiają się ludzie bez domów, bez pracy, bez horyzontu życiowego, nieustannie zagrożeni nagłą, paskudnie przypadkową śmiercią - czyli potencjalni uchodźcy.

Kondycja uchodźcy to nie fanaberia porzucenia własnego kraju, lecz poszukiwanie ratunku.

\section{Lekcja Ukrainy w Chojnicach}

Lekcję na zadany tu - także samej sobie jako nauczycielce - temat przeprowadziłam 13 października 2017 (piątek) w II Liceum Ogólnokształcącym im. Władysława Andersa w Chojnicach. Konspektem był zaproponowany tu układ artykułu, przebieg lekcji upodabniał się do przebiegu procesu myślowego w szkicu, lecz nie do końca z nim utożsamiał.

Lekturę wiersza poprzedziła rozmowa o datach „pechowych” (trzynastego w piątek) i pamiętnych, o datach klęsk, które czasem okazują się zwycięstwami, o cezurach. Uczennice i uczniowie odnosili się do takich dat w historii Polski (III rozbiór w 1795, daty powstań narodowych, 1 września 1939, 17 września 1939, 13 grudnia 1981). Historię Polski, tak ważną dla Polaków, zestawiliśmy z historią Ukrainy i jej dążeń oraz osiągnięć wolnościowych, tak ważnych dla Ukraińców. Potem odnieśliśmy te wstępne rozważania do daty powstania wiersza (tuż po pacyfikacji kijowskiego Majdanu) i szczególnej poetyckiej wrażliwości Bohdana Zadury, swego rodzaju „chwili ostrego widzenia”.

Drugim tematem, celowo retardującym głośną lekturę utworu poetyckiego, była rozmowa o tytule wiersza. I tu pojawiły się nieprzewidziane przeze mnie konteksty, które z radością odnotowuję, szczególnie że w lekcji wzięło udział kilkadziesiąt osób z klas I, II i III liceum, głównie o profilu humanistycznym, ale także te wszystkie, które po prostu chciały (na poddaszu chojnickiego liceum znajduje się ogromna sala, mieści się w niej nawet 
sto osób, mapa, tablice, tron dla gości specjalnych, i tak dalej). Obok skojarzeń oczywistych i przeze mnie w artykule przewidzianych, pojawiło się nawiązanie do Hotelu Rwanda (filmu) i do sytuacji w Syrii, ale także - i to właśnie ta niespodzianka asocjacyjna - do Hotelu Lambert jako siedziby i intelektualnego centrum polskiej Wielkiej Emigracji po powstaniu listopadowym (analogicznie do intelektualnej roli Majdanu jako ukraińskiej agory).

Ponieważ lekcja Ukrainy miała być w zamyśle także lekcją interpretacji, przed wspólną lekturą wiersza wprowadziłam kategorię osi interpretacyjnej i zasugerowałam możliwość interpretacji porównawczej z wierszem Mickiewicza Do przyjaciół Moskali. (Później zaowocowała ta możliwość propozycją zadania domowego dla osób chętnych.)

Głośnej lektury podjął się uczeń, który zamierza pójść do szkoły aktorskiej. Czytał z dobrą dykcją, a to, że trudność sprawiały mu nieznane ukraińskie nazwiska, wzmagało efekt autentyczności (nazwiska nic nie mówią, brzmią obco, inaczej, a jednak los tych ludzi nie jest nam, najpierw poecie, a potem czytelnikom obojętny; tu pojawił się wątek poezji interwencyjnej - w krótkiej perspektywie, która może okazywać się - w dłuższej perspektywie - obywatelską i empatyczną).

Wtedy zaproponowałam - bez żadnego komentarza - przytoczone w niniejszym artykule fragmenty z tomów Wilki żyja poza prawem. Jak Janukowycz przegrał Ukrainę oraz Szcze ne wmerła i nie umrze. Rozmowa z Jurijem Andruchowyczem.

Sama interpretacja wiersza była wypadkową uprzedniego ukontekstowienia (tło historyczne, asocjacje polityczno-wolnościowe, znaczenie tytułu, podstawowa wiedza o interpretacji) i gatunkowym nawiązaniem do długości wiersza (odczuwalnej mocniej po akcie odczytania). Tutaj w wielogłosie uczniowskim pojawiły się także kwestie quasi-litanijnej enumeracyjności; wyliczenie okazywało się przeciw-śmiertelne, przeciw-wanitatywne.

Wnioski zostały uzupełnione przez spojrzenie Ukraińca na Ukrainę zdystansu: odwołanie do Ołeksandra Bojczenki ijego książki 50 procent racji.

Taki podwójny i nieoczywisty duet, polskiego poety i jego empatii (gościnności) oraz ukraińskiego eseisty i jego dystansu, duet Zadury i Bojczenki, zamykał lekcję.

\section{Inne domknięcie}

W dniu, w którym skończyłam pisać ten tekst - 19 września 2017 roku - w klasie mojej córki (klasa Vd w Szkole Podstawowej nr $70 \mathrm{im.}$ Mikołaja Kopernika w Poznaniu) pojawił się nowy uczeń, Ilja spod Kijowa. Stąd dedykacja. 


\section{Bibliografia}

Andruchowycz Jurij (red.), 2014, Zwrotnik Ukraina, Wołowiec.

Bojczenko Ołeksandr, 2016, 50 procent racji, Zadura B., Zadura M.S. (przeł.), Lublin.

Kuczyńska-Koschany Katarzyna, 2015, Majdan, agora i grób (notatki na marginesie tomu „Zwrotnik Ukraina”). „Polonistyka. Innowacje” nr 1, s. 133-135.

Parafianowicz Zbigniew, Potocki Michał, 2015, Wilki żyja poza prawem. Jak Janukowycz przegrał Ukraine, Wołowiec.

Smoleński Paweł, 2014, Szcze ne wmerła i nie umrze. Rozmowa z Jurijem Andruchowyczem, Wołowiec.

Zadura Bohdan, 2014, Hotel Ukraina, w: Kropka nad i, Wrocław, s. 68-72.

\section{O Autorce:}

Katarzyna Kuczyńska-Koschany, prof. w IFP Uniwersytetu im. Adama Mickiewicza w Poznaniu, komparatystka, eseistka, prozaik. Zainteresowania badawcze: recepcja poezji francusko- i niemieckojęzycznej w Polsce, poezja i jej interpretacja, intersemiotyczność, kultura i Zagłada Żydów. Autorka książek: Rilke poetów polskich (2004; w druku wydanie II), Rycerz i Śmierć. O „Elegiach duinejskich” Rainera Marii Rilkego (2010; wyd. II, e-book, 2015), Interlinie w ciemności. Jednak interpretacja (2012), „Wsje poety Żydy". Antytotalitarne gesty poetyckie i kreacyjne wobec Zagłady oraz innych doświadczeń granicznych (2013), tomu prozy Zielony promień (2006), współautorka podręcznika Staropolskie korzenie współczesności (2004). Opiekunka naukowego Koła Miłośników Kultury i Literatury Żydowskiej „Dabru emet”. Obecnie kieruje Zakładem Badań nad Tradycją Europejską IFP UAM. 